\title{
Fra Stjepan Belić - priređivač Baromićeva glagoljskoga brevijara tiskanoga 1493. godine u Veneciji?
}

\begin{abstract}
Fra Stjepan Belić, franjevac trećoredac glagoljaš, živio je u zadnjim desetljećima 15. i prvim desetljećima 16. stoljeća, u vrijeme iznašašća tiska, otkrića Amerike i vrhunskih dostignuća rascvjetanoga humanizma. To je upravo istaknuto razdoblje zlatnoga doba glagoljaške kulture. Osim različitih i važnih službi koje je vršio u svojoj redovničkoj zajednici, 23. travnja 1494. imenovan je javnim učiteljem staroslavenskoga jezika u Kopru. Dopis o tome potpisao je službeni delegat fra Gabrijel Bruni.

U radu će se iznijeti dosad nepoznati podaci o fra Gabrielu Bruniju, koji je, uz obveze službe gvardijana, profesora, propovjednika, pisca i prepisivača, sudjelovao u ranoj fazi hrvatskoga tiskarstva, a u osobi fra Stjepana Belića prepoznat će se priređivača Baromićeva glagoljskoga brevijara iz 1493. u Veneciji.
\end{abstract}

Fra Stjepan Belić, franjevac trećoredac glagoljaš, živio je u zadnjim desetljećima 15. i prvim desetljećima 16. stoljeća, u doba iznašašća tiska, otkrića Amerike i vrhunskih dostignuća rascvjetanoga humanizma. Upravo je tada bilo zlatno doba glagoljaške kulture.

Tijekom druge polovine 15. stoljeća mnogi su hrvatski humanisti (latinisti) stvarali i bili zapaženi u svijetu, osobito na književnom polju, kao stručni i plodni pisci. Slijedili su ih svećenici i redovnici glagoljaške duhovnosti, istina u skromnijem obujmu, pridonoseći na kulturnom polju stvaranjem, objavljivanjem, upotrebljavanjem i prevođenjem mnogih teoloških, nabožnih i književnih djela. Zapaženo su sudjelovali u širenju tiskarstva preko liturgijskih priručnika, misala, brevijara, obrednika, psaltira za potrebe vjernika te početnica za potrebe đaka i stjecanje osnovnih knjiških i kulturno-duhovnih sadržaja. Stoga su mnogi sa strane pratili njihova materijalna, kulturna i duhovna dostignuća, obavještavajući o tome onodobnu kršćansku Europu.

\section{Zbivanja u zajednici franjevaca trećoredaca}

Uzmorjem od Kopra do Omiša glagoljaši su bili u doticaju sa zapadnim materijalnim, kulturnim i duhovnim zbivanjima. Među njima zapaženim su se 
kulturnim i duhovnim životom posebno isticali članovi Dalmatinsko-istarske provincije franjevaca trećoredaca, redovničke zajednice koja dugo nije imala središnju upravu. Franjevačke trećoredske zajednice i provincije nastajale su pod utjecajem opservanata i konventualaca, dakle franjevaca Prvoga reda. Takve su zajednice i provincije s trećoredskim samostanima kao osnovama postojale po Italiji, Njemačkoj, Francuskoj, Belgiji, ali i u drugim europskim zemljama.

U Dalmaciji i Istri, jadranskim regijama koje su u izravnom doticaju sa zapadnim svijetom, osnovana je Provincija franjevaca trećoredaca, koja se nadahnjivala na glagoljaškoj tradiciji Crkve u Hrvata i na pokorničkom duhu njezina redovničkoga usmjeritelja sv. Franje Asiškoga. Zbog toga je bila jedinstvena i posve neovisna o talijanskim provincijama. Provincija Dalmacije i Istre franjevaca trećoredaca, kako se službeno nazivala stoljećima, uspješno se materijalno, kulturno i duhovno razvijala te trajala tijekom ranoga novovjekovlja.

\section{Materijalni razvoj}

Većina današnjih trećoredskih samostana nastaje do kraja 15. stoljeća. To su: $S v$. Ivan u Zadru, Sv. Pavao na Školjiću (Galevcu), Sv. Mihovil na Zaglavu, Sv. Marija na Glavotoku, Sv. Marija Magdalena u Dubašnici te samostani u Kopru, Rabu, Cresu i Prvić Luci kod Šibenika. Budući da su bili dobro opskrbljeni materijalnim posjedima, mogli su podignuti lijepe samostanske crkve i samostane, koji su u arhitekturi i inventaru zadržavali redovnički duh siromaštva. Neke trećoredske crkve i samostani još uvijek pokazuju svoju solidnu srednjovjekovnu gradnju. Sami pak redovnici stjecali su poštovanje, primjerice, gradeći za sebe i susjede čatrnje za vodu (gušterne, gusterne, gustijerne).

\section{Kulturni razvoj}

Franjevci trećoreci glagoljaši školskom spremom nimalo se nisu razlikovali od drugih svećenika Katoličke crkve. Karizma im je usto nalagala da u bogoslužju, uz latinski, znaju i hrvatski crkvenoslavenski jezik. Također, uz materinski hrvatski znali su talijanski jezik. Svaki je trećoredski samostan imao i odgajao svoje žakne (đake), koji su u odgoju i obrazovanju do svećeničkoga ređenja prolazili sve žakanske staleže. ${ }^{1}$ Mnogi se u svom zvanju ostvaruju kao pisari, koji dragovoljno vjernicima sastavljaju oporuke, a subraći prepisuju i nabavljaju im tražene knjige. Takvima vjernici ostavljaju milostinju, kojom se oni gotovo uvijek koriste za nabavu pisarskoga materijala i knjiga. Zanimljivo je da su mnogi franjevci trećoreci glagoljaši bili prijatelji popova glagoljaša, koji im najčešće u svojim oporukama oporučuju knjige.

\footnotetext{
Usp. GREGOV 1990.
} 
Mnogi se u svom zvanju ostvaruju kao nositelji hodočasničkih zavjeta. Postojao je običaj preuzimanja i ispunjavanja zavjeta od zavjetovanih vjernika, koji nisu bili u mogućnosti izvršiti svoj zavjet. Stoga vrela bilježe franjevce trećorece glagoljaše na veoma udaljenim hodočasničkim lokacijama, poput grobova apostolskih prvaka i mjesta poznatih mučenika i svetaca. Mobilnost je znak otvorenosti prema materijalnim, kulturnim i duhovnim vrijednostima, a boravak u Svetoj Zemlji, na Sinaju, Camposteli, Asizu, Padovi, Rimu i na drugim sličnim mjestima silno je duhovno bogatstvo za posjetitelja. Stoga je izvjesno da su se samostanske zajednice obogaćivale posebnom duhovnošću nakon povratka svojih hodočasnika s tih mjesta.

\section{Duhovni razvoj}

Krajem 15. stoljeća franjevci trećoreci bore se za samostalnost i potpunu neovisnost od Prvoga franjevačkog reda. Sastavljaju penalne Konstitucije (1492.), u kojima se, među ostalim, zrcali svakodnevni život u ondašnjoj trećoredskoj zajednici. ${ }^{2}$ Konačno, 23. srpnja 1498. od pape Aleksandra VI. dobivaju povelju o samostalnosti. ${ }^{3}$ Nakon toga, početkom 16. stoljeća bore se za područje djelovanja u Crkvi, odnosno za dijeljenje svetih sakramenata vjernicima, koje usto potiču na molitvu i razne pobožnosti. Pastoralno su angažirani, poslužuju župne zajednice, cijenjeni su kao duhovni savjetnici, ispovjednici i teolozi na visini zvanja i suvremenih potreba. Nabavljaju duhovnu literaturu, naručuju vrijedna umjetnička djela itd.

Vrijedno je navesti neka zaslužna imena toga doba, kao što su fra Matej Zadranin (poznatiji kao Bošnjak-Mastilić), koji je angažiran u izdavanju Spovidi općene $(1492 .)^{4}$, zatim pisac, kroničar i pjesnik fra Šimun Klimantović ${ }^{5}$, fra Blaž Šibenčanin, fra Franjo Rabljanin, fra Ivan Galić Makedonac, javni bilježnik Martin Knežić ${ }^{6}$, potom fra Jakov Belić, fra Antun Šibenčanin, fra Ivan Pokrajčić i fra Marko, koji je prevoditelj Mare magnum, ali i mnogi drugi, poput redovnika svetoga života fra Maksima iz Raba. ${ }^{7}$ Svi oni djelovali su u doba procvata hrvatskoga glagoljaštva. U tom duhu i u to doba djelovao je i jedan franjevac trećoredac glagoljaš pravne i teološke izobrazbe, koji je bio vrstan poznavatelj staroslavenskoga jezika i prvi poznati njegov učitelj. Riječ je o Rabljaninu fra Stjepanu Beliću, kojim ćemo se pozabaviti u ovom članku.

\footnotetext{
2 Usp. RUNJE 2001: 183-193.

3 IVANČIĆ 1910a. Br. XXXIII: 35-36.

4 RUNJE 1990: 147-158.

5 RUNJE 2015.

6 RUNJE 2009: 34.

7 Više o njima u IVANČIĆ 1910; HFBL 2010; RUNJE 2012.
} 


\section{Životopis fra Stjepana Belića}

Premalo je arhivskih podataka o fra Stjepanu Beliću, rodom Rabljaninu. Budući da se radi o prvom službeno potvrđenom učitelju staroslavenskoga jezika (1494.) i vjerojatno uredniku Baromićeva brevijara (1493.), svaki je podatak o njegovu životu i djelovanju osobito vrijedan.

Fra Stjepan Ivančić, prvi put pišući o fra Stjepanu Beliću, navodi da je rođen oko 1470. i da je umro oko $1550 .{ }^{8}$ Drugi put, u Povijesnim crtama (1910.), donijevši njegov kratak životopis, drukčije navodi da je rođen oko $1460 .{ }^{9}$ Nije poznato odakle Ivančiću ti podaci jer je prvi siguran podatak onaj koji donosi Vjekoslav Štefanić, kada 7. listopada 1493. govori o trećoredskom samostanu u Kopru: „Fra Stjepan iz Raba delegiran od gvardijana fra Martina iz samostana sv. Marije Magdalene u Kopru, trećeg reda sv. Franje od pokore, te podnosi biskupu papinsko pismo, neka naloži fra Tomi iz Trsta, minoritu opservantu i drugim klericima i laicima da ne uznemiruju gore rečene fratre (dakle, trećorece) gradeći im s leđa neku kuću“. ${ }^{10}$

Sam pak proces, doduše bez navoda fra Stjepanova imena, počeo je i ranije. Šest mjeseci kasnije, 15. travnja 1494., doznaje se sljedeće: „Pošto je pred kratko vrijeme umro fra Martin iz Zadra, trećoredac sv. Franje, kanonik Giovanni de Vanto traži u ime kaptola da se fra Stjepan iz Raba i fra Ivan, drugovi pokojnoga, udalje od kuće, vrta i cimiterija sv. Andrije u Kopru, što ih je on odavno uživao"."11 Proces oko vlasništva kuće i zemljišta u Kopru nastavio se dalje, pa tako i nakon fra Martinove smrti, kada je fra Stjepan izabran za gvardijana svoje samostanske zajednice. Na kraju je uspio dokazati pravo na korištenje nekretninom. Naime, u dokumentu od 7. rujna 1494. navodi se da su neki poslije fra Martinove smrti razgrabili i skrili samostanska dobra. Fra Stjepan obratio se Aleksandru VI., koji je naložio koparskomu biskupu Jakovu Valaresu da provede cjelovitu istragu i donese pravorijek. Biskup je potom ovlastio krčkoga arhiđakona Dominika da izvrši navedeni zadatak. Tako je koparski bilježnik 15. rujna 1494. pročitao u katedrali i oglasio ekskomunikaciju. Budući da se nitko nije oglasio, sljedeće je nedjelje, 22. rujna 1494., ponovo pročitao papinski dekret na neutralnom mjestu, u samostanskoj crkvi franjevaca konventualaca. ${ }^{12}$ Napetosti između trećoredaca i opservanata početkom 1490-ih trajale su sve do 1530-ih, kada su trećoreci kompromisno smješteni uz crkvu sv. Grgura u Kopru. ${ }^{13}$ Štefanić pomišlja da je

\footnotetext{
8 IVANČIĆ $1887: 25$.

9 IVANČIĆ 1910: 167.

10 ŠTEFANIĆ 1956: 220.

11 Isto: 221.

12 ŠTEFANIĆ 1956: 221.

13 „ک̌.U.dz.B (1492) Kada umri kralj Matijaš ugarski dobri gospodin i vitez i tada Cokolanti pridoše u Kopar" (JELIĆ 1906: 45).
} 
sam fra Gabriel Bruni išao do Rima u korist trećoredaca. Ipak, čini mi se da je taj put i pothvat mogao obaviti sam fra Stjepan Belić jer se u drugoj polovini 1493., nakon obavljena posla u Veneciji, nalazio upravo u Kopru.

Nekoliko se puta iskazao vješt u sudskim procesima; prvi put kada se vodio proces protiv jednoga svećenika, drugi put kada su se fratri 1507. sporili sa župnikom u Sutomišćici, te konačno prije smrti, kada se sa srođenom sestrom Anicom sporio oko kuće koja se nalazila pokraj crkve sv. Luke u Zadru. Smrt ga je iznenada zatekla u Anconi, a fratri su proces okončali u svoju korist. ${ }^{14}$

Fra Stjepan u dvama je navratima, između 1507. i 1513., bio provincijal. Moguće je da je sudjelovao u izdanjima glagoljskih knjiga u Senju. Naime, u kolofonu Naručnika plebanušev iz 1507. stoji da se imena ,nikih meštarb $i$ doktrvb kih imna ne izriču se za ukloniti se tašće slve (...) ". ${ }^{15}$ Tada nije bilo mnogo onih koji su imali visoko obrazovanje. Stoga se možemo zapitati nije li među njima bio i fra Stjepan Belić?

Fra Stjepan Belić kao arttium doctor 24. kolovoza 1519. pred javnim bilježnikom sastavlja donaciju, u kojoj svomu nećaku kleriku Ivanu oporučuje kuću pokraj sv. Luke u Zadru. ${ }^{16}$ Isti je bilježnik 24. veljače 1523. napisao sljedeće: „Personaliter constituta sui juris mulier domina Antonia arbensis diocesis uti soror et heres testamenti qu. Venerabilis domini fratris Stephani Belich Arbensis tertii ordinis Sti Francisci de penitentia (...) “, koji je umro u Ankoni, službeno traži posjed kuće pokraj crkve sv. Luke. ${ }^{17} \mathrm{~S}$ ovim doznajemo da je fra Stjepan umro u Ankoni početkom 1523.

U našemu osvrtu posebnu važnost pridajemo javnom dokumentu i autoru dokumenta, maestru fra Gabrielu Bruniju, franjevcu konventualcu, delegatu franjevačkoga generala Francesca Sansone. Naime, maestro fra Gabriel Bruni 23. travnja 1494. imenovao je javnim učiteljem glagoljice i staroslavenskoga jezika oca fra Stjepana Belića s boravištem u Kopru.

\section{Maestro fra Gabriel Bruni}

Prvu sigurnu vijest o fra Gabrielu Bruniju doznajemo iz 1459., kada fra Antonio Marcelo, provincijal Provincije sv. Antuna, zajedno s inkvizitorom fra Gabrielom Brunijem, službeno pita Vijeće desetorice u Veneciji obdržava li se zakonski propis od 17. veljače 1450., kojim službenici Republike trebaju pomagati inkvizitorima u njihovoj službi i smiju li dvanestorica u inkvizicijskoj službi

\footnotetext{
14 RUNJE 2010: 53.

15 NAZOR 1978: 64-65.

16 DAZD. SZN. Matteo Sonzonio, sv. III, svešč. 3, 25. VIII. 1519.

17 DAZD. SZN. Matheus Sonsonius, sv. III, 24. II. 1522. /23/.
} 
nositi oružje. ${ }^{18}$ Ipak, navodi se da je 1457. bio osobni ispovjednik milanskomu knezu Francescu Sforzi. ${ }^{19}$ Potom ga 1464. zatječemo kao gvardijana samostana sv. Joba u Veneciji te 1472., kada ga je papa Siksto IV. angažirao oko ujedinjenja franjevačke vikarije Brescia s vikarijom sv. Antuna. ${ }^{20}$

Među časnim i brojnim uzvanicima 13. veljače 1469., prilikom posvete oltara u crkvi Santa Maria Gloriosa, u samostanu franjevaca konventualaca Ai Frari u Veneciji bio je i fra Gabriel Bruni, kao autor pergamentnoga dokumenta, položenoga u posvetni oltar (scriba me fratre Gabriele Bruno Veneto) ${ }^{21}$ Vrlo brzo, krajem 1470-ih i početkom 1480-ih fra Gabriel Bruni gvardijan je spomenutoga samostana. ${ }^{22} \mathrm{Na}$ toj dužnosti 15. listopada 1478. sklapa ugovor s Bratovštinom sv. Roka u Veneciji.

Uz službu gvardijana, profesora, propovjednika, pisca i prepisivača, fra Gabriel Bruni od 20. travnja 1484. vrši službu inkvizitora u Veneciji. ${ }^{23}$ Veliku je strast pokazivao prema tiskarstvu. Upravo je on sastavio abecedno kazalo prvomu izdanju glasovite Paganinijeve Biblije, tiskane 7. rujna 1492. u Veneciji. ${ }^{24}$ Ta je Biblija 1490-ih doživjela barem osam različitih izdanja. ${ }^{25}$ Fra Gabriel je 1493. priredio i u venecijanskoga tiskara Giovannija Co de Ca' iz Parme tiskao djelo Bernardini Ilicini medicinae ac philosphie discipuli in Triumphorum clarissimi poetae Francisci Petracae expositio. ${ }^{26}$ Otprilike tada, 7. kolovoza 1493., general reda fra Franjo Sansone imenovao ga je komisarom Provincije sv. Jeronima u Dalmaciji, nakon smrti provincijala fra Bartola de Sanctisa. ${ }^{27}$ Tri dana kasnije, 10. kolovoza 1493., general određuje da se ostavština preminuloga provincijala dodijeli netom imenovanomu komisaru fra Gabrielu Bruniju. ${ }^{28}$

Ta služba nije mu dodijeljena slučajno. Kao aktivnom, poštovanom i cijenjenom redovniku, general je triput uzastopce povjeravao važne i odgovorne službe na dobro braće i zajednice franjevaca konventualaca. Najprije je 1488. bio provincijal

18 „1459. - Ministro della Prov. Del Santo, P. M. Antonio Marcello, e il P. Inquisitore, P. M. Gabriele Bruni di Venezia, domandano ai Capi del Cons. Dei X che sia osservata la parte 1450, 17 febbraio relativa agli ufficiali che devono assistere gli Inquisitori, cioe che i dodici ufficiali dell'Inquisizione possono portare armi (ASVen, SMGlo. Dei Frari, b 91, perg. 50) “(SARTOZI 1989: 408).

BALISTRERI 1972: s. v. Bruno (Brunus, Bajenus) Gabriele. BALISTRERI 1972: s. v. Bruno (Brunus, Bajenus) Gabriele. SARTOZI 1989: 409.

Isto: $671,1926$.

Isto: 417.

Isto: 918 (7. IX. 1492.).

BALISTRERI 1972: s. v. Bruno (Brunus, Bajenus) Gabriele.

SARTORI 1989: 918.

ŽUGAJ 1989: 47; ROF MCON 1989: br. 2275, br. 2276.

ROF MCON 1989: br. 2282 (10. VIII. 1493.). 
u Svetoj Zemlji, potom je 1491. bio inkvizitor u Provinciji sv. Antuna (Santo), a 1493. komisar u Svetoj Zemlji i konačno u Provinciji sv. Jeronima u Dalmaciji. Premda je bio iz Venecije i živio u Veneciji, često je bio izvan svoga grada u vizitacijama provincija i samostana. Zbog toga je svoga subrata fra Germana de Casalija imenovao svojim zakonskim delegatom, kojeg u pojedinim slučajevima ovlašćuje da može posegnuti i za brachium saeculare, a braći redovnicima zapovijeda da ga poštuju i prihvaćaju kao njega osobno. Taj je dokument osobno napisao 10. srpnja 1497. u svojoj venecijanskoj rezidenciji. ${ }^{29}$

Fra Gabriel javlja se više puta. Svakako je zanimljiva njegova intervencija u diskusiji s venecijanskim patrijarhom 5. travnja 1499. ili nastup u crkvi sv. Bartola 11. kolovoza 1504., kada se javlja kao provincijal Provincije Romanje, tj. Istoka i Grčke. ${ }^{30}$ Fra Gabrijel Bruni bio je Provincijal Romanje od kraja 15. stoljeća. ${ }^{31}$ Pred blagdan Porcijunkule, 31. srpnja 1488., braća konventualci u Sacro Convento u Asizu pripremaju se za doček provincijala i magistra fra Gabriela Brunija, ,,ministri provincie orientalis " ${ }^{32}$ Fra Gabriel Bruni bavio se i prevođenjem s latinskoga na talijanski jezik. Godine 1492. preveo je na talijanski djelo De arte equorum G. Ruffija, koje je tek 1554. i tiskano. ${ }^{33}$ Ballistreri, pozivajući se na Superbija, veli da je Bruni neka djela i sam napisao. O njima danas nema ni traga.

Fra Gabriel Bruni umro je 26. travnja 1515. ${ }^{34}$ Pokopan je u Santa Maria Gloriosa u Frariju u Veneciji. S provincijom franjevaca konventualaca u Dalmaciji osobno je bio povezan 1490-ih, nakon što je, kako je spomenuto, imenovan njezinim službenim delegatom ili komisarom. ${ }^{35} \mathrm{Za}$ nas je posebno važan službeni dopis, kojim fra Gabriel Bruni 23. travnja 1494. fra Stjepana Belića imenuje javnim učiteljem glagoljice u Kopru. Dopis počinje sljedećom rečenicom: ,,U Kristu predragom bratu (fratru) Stjepanu Belić, Kopar 24. travnja 1494. “. ${ }^{36}$ Tada je fra Stjepan već dokazani predstavnik svoje redovničke zajednice. ${ }^{37} \mathrm{Za}$ fra Gabrielova boravka u Kopru 23. travnja 1494., fra Stjepan Belić, koji je tada bio koparski gvardijan i stručni poznavatelj staroslavenskoga jezika, ovlašten je da poučava

\footnotetext{
29 SARTORI 1989: 417 (10. VII. 1497.).

30 Isto: 417.

31 ROF MCON 1989: br. 500, br. 609, br. 1298. Pod br. 520 naveden je kao provincijal Svete Zemlje. Riječ je o istoj zajednici franjevaca konventualaca osnovanoj još 1217 . U njegovo je doba imala 5 samostana na Cipru i jedan na Sionu u Jeruzalemu. Usp. ROF MCON 1989: br. 1298, bilj. 1.

CENCI 1975: 832.

BALISTRERI 1972: s. v. Bruno (Brunus, Bajenus) Gabriele.

SARTORI 1989: 1266.

BIGONI 1973: 174.

Cijeli dokument vidi u IVANČIĆ 1910a. Br. IV: 164-165.

ŠTEFANIĆ 1956: 221.
} 
staroslavenski, teologiju i druge teološke discipline te da može slaviti svetu misu u različitim oratorijima.

\section{Fra Gabriel Bruni i fra Stjepan Belić}

Vjekoslav Štefanić, osvrćući se na tekst imenovanja fra Stjepana Belića, među ostalim piše: ,Iz toga dokumenta (koji je, kako se iz isprekidanoga teksta razabira, loše sačuvan) može se razumjeti da je život fra Stjepana uvijek bio za pohvalu te da se brinuo se za spasavanje duša, ali da on želi da se bavi i knjigom, kako bi mogao biti još korisniji: komesar fra Gabrijel veli da se fra Stjepan svojim životom, vladanjem i slavenskim jezikom, kojim svaki dan služi misu, toliko odlikovao, da su ga s pravom njegovi starješine proglasile posve sposobnim (za nastavnika); stoga mu on daje licenciju da može u svakom gradu, gdje to bude potrebno, slobodno predavati gramatiku i druge predmete iz teologije ". ${ }^{38}$ Potom, osvrćući se na Stjepana Ivančića, koji pomišlja da bi autor Brozićeva brevijara iz 1561. mogao biti upravo fra Stjepan Belić, zaključuje: „,No budući da je Brozićev brevijar gotovo nepromijenjeno Baromićevo izdanje iz g. 1493., moramo stvar prebaciti na ovu godinu. Ništa se pozitivno ne može reći, ali redaktor Baromićeva brevijara, odnosno njegova predloška, bio je vrlo vjerojatno neki franjevac, koji je poznavao zadarski kalendar. A to je mogao biti fra Stjepan Belić ". ${ }^{39} \mathrm{U}$ potvrdu Štefanićeva zaključka navedimo neke okolnosti, koje idu u prilog tomu da je fra Stjepan redaktor Baromićeva brevijara, tiskanoga 1493. u Veneciji.

Bruni piše da je od mnogih čuo samo pohvalno o fra Stjepanu Beliću, koji mu je kazao da bi i on želio nešto tiskati - eoque ob id cupias literis aliquantulum operam dare. Potom Bruni, koji je bio dokazani priređivač tiskanih knjiga, svjedoči da su starješine fra Stjepana, koji svaki dan slavi svete tajne na staroslavenskom jeziku, dignitatem peridoneum denunciaverint, proglasili predostojnim časti. Oni su ga poznavali i predložili za važnu službu. Nije li to bila suradnja na tiskanju brevijara? Belić se upravo u vrijeme njegova tiskanja nalazi u Kopru.

Baromićev brevijar ugledao je svjetlo dana 13. ožujka 1493. u Veneciji, odakle je i fra Gabriel Bruni, koji se i sam bavi izdavačkom djelatnošću. Upravo se tada Baromić nalazi kod poznatoga tiskara A. Toresanija. Kao preporučitelj preko Belića mogao mu je biti upravo Bruni, koji je zbog svojih konventualaca cijenio trećorece iz Kopra.

Naime, Baromićev brevijar bio je veliko i zahtjevno djelo za tisak. Dugo se priređivao. Fra Matej Mastilić tiskao je Spovid (1492.) uz pomoć rapske obitelji Grimalarka. U to vrijeme i fra Matej živi u Rabu, s kojega je rodom fra Stjepan

\footnotetext{
Isto: 222 .

$39 \mathrm{Na}$ istome mjestu.
} 
Belić. U to doba on boravi u Veneciji, vjerojatno dulje od dviju godina, pripremajući tekst, izlijevajući glagoljska slova i vršeći razne nužne radnje i vještine potrebne tiskarstvu. Kopar je, u odnosu na Zadar i Rab, mnogo bliži Veneciji. Nakon što je 13. ožujka 1493. konačno tiskan, fra Stjepan dolazi u svoj samostan u Kopru, žrtvujući se u koparskoj sredini nesklonoj glagoljašima.

\section{Trećoredski elementi u Baromićevu brevijaru}

Biserka Grabar, obrađujući kalendar Baromićeva brevijara, istaknula je obilnu zastupljenost franjevačkih blagdana - čak dvadeset i jedan. ${ }^{40}$ Smatram da je fra Stjepan Belić pripremio tekst toga Brevijara, koji je tiskao Andrija Toresani. Za tisak ga je pripremio Blaž Baromić, a sam tekst knjiški je dotjerao fra Stjepan Belić. Indikativno je da je riječ o knjizi koja je bila namijenjena franjevačkoj trećoredskoj zajednici. Premda je manjega formata, pridodan mu je dio misala i rituala te opširne upute za moljenje časoslova, čime je knjiga pogodna za razna misijska i pastoralna putovanja te za upute u redovničke i svećeničke službe mladim žaknima.

U Baromićevu kalendaru posebno se ističu naglašeno franjevački trećoredski blagdani: ${ }^{41}$

26. VIII.

27. IX.

27. X.

19. XI.
Lodovika $^{42}$ is krala Francie tret(o)ga $\mathrm{r}(\mathrm{e}) \mathrm{d}(\mathrm{a})$

Elzearie ${ }^{43}$ is tretoga reda du(plb) veli

Važno je zapaziti da se sva četiri blagdana označuju s duplex maior, najvećom liturgijskom oznakom. Premda spadaju u krug franjevačkih svetaca, oni su u kalendaru istaknuti kao sveci Trećega franjevačkoga reda. Taj je red postao službeno crkveno priznat 1449. Slično je u ovom kalendaru stavljeno i za sv. Klaru. Njezin blagdan označen je kao duplex maior i slavi se kao duplex veli u redu klarisa. Dočim je za Prijenos svete Klare, 2. listopada, blagdan označen kao duplex mali za cijeli franjevački red. Smatram potrebnim naglasiti da su i u kalendaru četiri

\footnotetext{
40 GRABAR 1984: 159-180.

41 Isto: 164-165.

42 Francuski je kralj Luj IX. Sveti trećoredski čašćeni svetac sv. Ljudevit.

43 Trećoredac sv. Elezarije, svetac je crkve u Aptu, a službeno je svetac od 1371.

44 Toga datuma slavi se prijenos tijela sv. Ivona, svećenika i ispovjednika, u bretonski gradić Treguier. Grabar (1984: 164-165) je mislila da su sv. Elzearije i sv. Ivon s Baromićevim brevijarom prvi put spomenuti u glagoljaškoj sredini. Međutim, oba se sveca navode već u dvodijelnom glagoljskom brevijaru Illirico 5-6 u 14. stoljeću.
} 
ova blagdana prvi put označena kao blagdani tretoga reda. Bilo je i drugih trećih redova, a ovdje se taj treći poistovjećuje s Trećim redom sv. Franje Asiškoga.

U popisu blagdana, koji su prvi put navedeni u glagoljskom kalendaru, nalaze se sljedeći franjevački blagdani: ${ }^{45}$

16. I.

17. V.

27. $\mathrm{V}$.

20. VI.

3. VII.

2. VIII.

19. VIII.

26. VIII.

17. IX.

8. XI.
Pet svetih mučenika franjevačkoga reda

Prijenos sv. Bernardina

Oktava sv. Bernardina

Oktava sv. Antuna

Sv. Bonaventura

Posveta crkve Svete Marije u Asizu (Porcijunkula)

Oktava sv. Klare

Oktava sv. Ljudevita

Rane sv. Franje

Prijenos sv. Ljudevita biskupa

Posebno vrijedi naglasiti da se za trećoredske blagdane u sanktoralu nalazi 9 lekcija za sv. Ivona, 9 lekcija za sv. Elzearija, 9 lekcija za sv. Ljudevita kralja i 9 lekcija za sv. Elizabetu. Također, vrijedno je naglasiti da se obilne lekcije za sv. Ivona i sv. Elzearija nalaze upravo u Baromićevu brevijaru.

Ovdje bi bilo vrijedno istaknuti, što je već učinila Biserka Grabar, velik broj svetaca koji su se štovali na zadarskom i ninskom području. Neupitno je da su Zadar i Nin bili kolijevke franjevaca trećoredaca i da je upravo zadarsko područje povezalo trećorece rasijane po otocima i uzobalju u jednu jedinstvenu zajednicu - Provinciju. ${ }^{46}$ Dok se na Školjiću popisuju penalne Konstitucije, koje propisuju način života trećoredaca i za prekršitelje navode ozbiljne kazne, u Veneciji se priprema i uređuje značajan priručnik - brevijar ili časoslov. U vrijeme tiskanja Baromićeva brevijara (13. ožujka 1494.) franjevci trećoreci nisu imali punu samostalnost. Bili su podložni konventualskomu provincijalu i u isto su se vrijeme borili za stjecanje samostalnosti. Opservanti su dugo imali pretenziju da se trećoreci sjedine s njima. Koliko znamo, franjevci trećoreci nisu imali nekih napetosti s konventualcima, a samostalnost su zadobili 24. kolovoza 1499. od pape Aleksandra VI. U vrijeme ovisnosti trudili su se steći što više samostalnosti. Jedan od važnih događaja bio je kapitul trećoredskih redovnika na Školjiću (Galevcu), gdje 22. travnja 1492. kodificiraju penalni zakonik sličan onima iz drugih redovničkih i svećeničkih zajednica. Nekoliko odredaba, kapitula, kao da upozorava na opasnost za zajednicu. Tako 27. kapitul glasi: „,Ki bi propovidal'

45 GRABAR 1984: 163-166.

46

Usp. RUNJE 2011. 
riči ili učinenie, ča se bratie dogovore i učine meju sobom na kapituli ili inda, tomu pokora 15 dan v' kladi v' kruhu i o vodi, i v'saki dan' dokle e v'kladi po ednu dešiplinu da mu se da" ${ }^{47}$

Veza franjevaca trećoredaca s konventualcima ostala je čvrsta. Trećoreci održavaju i kapitul 1511. u konventualskom samostanu sv. Franje u Krku. U Šibeniku su fratri s Prvića rado navraćali konventualcima u Šibenik. U molbi apostolskom vizitatoru (1579.) trećoreci se hvale dobrim odnosima s konventualcima. Opservanti s hrvatskoga prostora bili su pod izravnim utjecajem opservanata s Apeninskoga poluotoka te stoga nisu bili blagonakloni prema glagoljašima. Konventualci su sudjelovali i u velikom pothvatu tiskanja glagoljskoga misala 1528., franjevca trećoreca fra Pavla Modrušanina, a sam fra Pavao, zajedno s fra Bernardinom, živio je neko vrijeme u konventualskom samostanu Ai Frari u Veneciji.

\section{Ekskurs o glagoljici i staroslavenskom jeziku}

Biserka Grabar, navodeći posebnosti Baromićeva kalendara, piše: , Kao posebnu zanimljivost ovoga kalendara treba spomenuti činjenicu da uz blagdan sv. Ćirila $i$ Metoda (14. II.) stoji oznaka dupls svoemb eziku za što ne nalazimo potvrde ni u kojem drugom glagoljskom kalendaru " ${ }^{48}$ Čini mi se da nas ta pojedinost upućuje upravo na franjevce trećorece. Naime, istaknutom činjenicom baš za blagdan sv. Ćirila i Metoda, koji se slavi kao liturgijska svetkovina dupleks i to na svojemu jeziku, želi se naglasiti da su sv. Ćiril i Metod slavenski apostoli koji se svečano slave među glagoljašima u narodu koji ima svoj jezik u liturgiji. Taj jezik imaju Hrvati, Srbi, Bugari i Makedonci. Svi oni slave Svetu braću kao svoje apostole. Sveta su im braća dala liturgijske knjige na njihovu jeziku, zapisane njihovim pismima. Tada je bilo opće uvjerenje da im je sv. Jeronim preveo Sveto pismo na slavenski jezik i da im je složio pismo. U to su posebno vjerovali, za razliku od drugih, franjevci trećoreci.

Jedva da je potrebno istaknuti kako sv. Jeronim nije mogao prevesti Sveto pismo na slavenski jezik jer su se slavofone skupine na ovim prostorima pojavile dva - tri stoljeća poslije njega. Dinko Zavoreo, govoreći o tome krajem 16. stoljeća, zabilježio je kako jedino trećoreci pravilno misle da je sv. Jeronim iznjedrio pismo bukvicu (glagoljicu), a da su prijevod na slavenski (staroslavenski) jezik dala Sveta braća. ${ }^{49}$ Pritom priznaje kako je ranije krivo mislio da je sv. Jeronim preveo Bibliju na staroslavenski. Ispravno misle jedino trećoreci i u svojim brevijarima

\footnotetext{
IVANČIĆ 1910b. Br. I: 219.

48 GRABAR 1984: 162.

49 ŠTEFANIĆ 1963: 39.
} 
čitaju i naučavaju ispravno. Jeronim je sastavio azbuku, a liturgijske su knjige prevela Sveta braća. Tako krajem 16. stoljeća piše taj Šibenčanin.

Vrijedno je navesti da taj naziv svojem jeziku donosi i tiskani Brozićev brevijar. Premda je uglavnom riječ o kopiji Baromićeva brevijara, činjenica je da su jedino trećoreci vjerno slijedili mišljenje da su Sveta braća prevela Sveto pismo na staroslavenski jezik, a da je glagoljicu izumio sv. Jeronim. Zavoreo tvrdi da su još samo trećoreci držali sv. Ćirila i Metoda prevoditeljima Biblije, a sv. Jeronima sastavljačem azbuke. ${ }^{50}$ Tijekom 17. stoljeća i trećoreci su prihvatili krivo poimanje da im je sv. Jeronim prevoditelj Svetoga pisma.

\section{Zaključak}

Na temelju vrela i literature može se zaključiti da je franjevac trećoredac fra Stjepan Belić tekstološki priređivač Brevijara Blaža Baromića, koji je tiskan 13. ožujka 1493. u Veneciji. Frane Paro u svojoj Typographia glagolitica piše: „Nažalost, nemamo svjedočanstava o tome koji je naš pismeni čovjek - glagoljaš - bio Torresanu i Baromiću pri ruci u poslovima slaganja Brevijara. Malo je vjerojatno da je Baromić, i uz najbolju volju, mogao sam složiti čitavu knjigu ". ${ }^{51}$ Malo bi tko Baromiću i Torresanu mogao biti bolji suradnik pri izdavanju doli fra Stjepan Belić, koji je bio priznati znalac staroslavenskoga jezika s boravištem u nedalekom Kopru. O fra Stjepanu još su to mislili zaslužni proučavatelji hrvatskoga glagoljaštva, fra Stjepan M. Ivančić, Vjekoslav Štefanić i fra Leonard Tandarić.

\section{Bibliografija}

Izvori

BIGONI, Giacomo. 1973. L'archivio conventuale di S. Francesco di Cherso in Istria: inventario 1387-1948. Firenza: Sansoni.

CENCI, Cesare. 1975. Documentazione di vita assisana 1300 - 1530. Vol. III. Grotaferrata: Collegio San Bonaventura.

DAZD [Državni arhiv u Zadru]. SZN [Spisi zadarskih notara]. Matteo Sonzonio (Matheus Sonsonius). Sv. III.

IVANČIĆ, Stjepan. (prir.). 1910a. Prilozi odnoseći se na povjest i na staro-slavensko bogoslužje OO. Samostanskog III Reda S. O. Franje u Dalmaciji, Kvarneru i Istri,

\footnotetext{
50 Isto: 39.

51 PARO 1997: 100.
} 
Petar Runje - Fra Stjepan Belić - priređivač Baromićeva glagoljskoga brevijara tiskanoga 1493....

a to Izprave, Pečatnice, Ostavštine, Namještaji, Povlastice, Dokaznice, Pohvalnice, Naredbe. U IVANČIĆ 1910.

IVANČIĆ, Stjepan. (prir.). 1910b. Nešto rukopisne glagolice u hrvatsko-primorskom narječju koncem XV i početkom XVI vieka od O. Šimuna Klimantovića i od O. Šimuna Glavića. U IVANČIĆ 1910.

JELIĆ, Lucas. 1906. Fontes historici Liturgiae glagolito-romanae. A XIII ad XIX saeculum. Vegliae (Krk).

ROF MCON 1989. Regesta Ordinis Fratrum Minorum Conventualium 1 (1488-1494). A cura di Gustavo Parisciani. Padova: Centro Studi Antoniani.

SARTORI, Antonio. 1988. Archivio Sartori: Documenti di storia e arte Francescana. A cura di Giovanni Luiseitto. Vol. III. Padova: Biblioteca Antoniana, Basilica del Santo.

\section{Literatura}

BALISTRERI, Gianni. 1972. „Bruno (Brunus, Bajenus) Gabriele“. U Dizionario Biografico degli Italiani. Vol. 14. Roma: Istituto della Enciclopedia italiana.

GRABAR, Biserka. 1984. Tiskani glagoljski Baromićev brevijar. Slovo 34: 159-180.

GREGOV, Nikola. 1990. Školovanje u Provinciji franjevaca trećoredaca glagoljaša [Novaja i vethaja 1]. Zagreb: Provincijalat franjevaca trećoredaca.

HFBL 2010. Hrvatski franjevački biografski leksikon. Ur. Franjo Emanuel Hoško, Pejo Ćošković, Vicko Kapitanović. Zagreb: Leksikografski zavod Miroslav Krleža.

IVANČIĆ, Stjepan. 1887. Poraba glagolice kod redovnika III. Reda sv. Franje po Dalmaciji, Istri i Kvarneru. Zadar: Brz. kat. „hrv. tiskarne“.

IVANČIĆ, Stjepan. 1910. Povjestne crte o samostanskom III Redu sv. O. Franje po Dalmaciji, Kvarneru i Istri i poraba glagoljice u istoj redodržavi. Sa prilozima. Zadar: Odlikovana tiskarna E. Vitaliani.

NAZOR, Anica. 1978. Zagreb riznica glagoljice. Katalog izložbe. Zagreb: Nacionalna i sveučilišna biblioteka.

PARO, Frane. 1997. Typographia glagolitica. Zagreb: Matica hrvatska.

RUNJE, Petar. 1990. Prema izvorima. Rasprave i članci o hrvatskim franjevcima trećoredcima glagoljašima [Novaja i vethaja 2]. Zagreb: Povijesno društvo otoka Krka, Provincijalat franjevaca trećoredaca.

RUNJE, Petar. 2001. Fra Šimun Klimantović i Konstitucije 1492. U Iskoni bê slovo / Zbornik radova o Glagoljici i glagoljašima zadarskog kraja i crkvi svetog Ivana Krstitelja, ur. Antun Badurina [Novaja i vethaja 7], 183-193. Zagreb: Kršćanska sadašnjost, Provincijalat franjevaca trećoredaca.

RUNJE, Petar. 2009. Svećenici javni bilježnici. Javni bilježnik 31: 33-39.

RUNJE, Petar. 2010. „Belić Stjepan“. U HFBL 2010: 53.

RUNJE, Petar. 2012. Prema izvorima II. Rasprave i članci o hrvatskim franjevcima trećoredcima glagoljašima. Ur. Tomislav Galović [Novaja i vethaja 9; Krčki zbornik 68, Posebno izdanje 61]. Krk-Zagreb: Povijesno društvo otoka Krka, Provincijalat franjevaca trećoredaca glagoljaša. 
RUNJE, Petar. 2015. Fra Šimun Klimantović u svom vremenu. Ogulin: Ogranak Matice hrvatske.

ŠTEFANIĆ, Vjekoslav. 1956. Glagoljaši u Kopru, god. 1467-1806. Starine JAZU 46: 203-329.

ŠTEFANIĆ, Vjekoslav. 1963. Tisuću i sto godina od moravske misije. Slovo 13: 5-42.

ŽUGAJ, Marijan. 1989. Hrvatska provincija franjevaca konventualaca nekad $i$ danas. Zagreb: Provincijalat franjevaca konventualaca.

\section{Friar Stjepan Belić - Editor of Baromić's Glagolitic Breviary from 1493 in Venice?}

Friar Stjepan Belić, a Glagolitic Franciscan tertiary monk, lived in the last decades of the $15^{\text {th }}$ and in the first decades of the $16^{\text {th }}$ century, at the time of the invention of book printing, the discovery of America and the pivotal achievements of a flourishing Humanism. That was just the golden age of the Glagolitic culture. Beside the various and important offices he was holding in his province, on $23^{\text {rd }}$ April 1494 friar Belić was declared a public teacher of Old Slavonic tongue through a letter of appointment signed by the official delegate friar Gabriel Bruni.

The paper will present previously unknown facts about friar Stjepan Belić who, apart from being active as a head of a monastery, professor, preacher, writer and copyist, participated in the early stage of book printing and can possibly be recognised as the editor of Baromić's Glagolitic book of hours from 1493 in Venice.

Keywords: fra Stjepan Belić, fra Gabriel Bruni, Baromić’s Glagolitic Breviary, Glagolitic Franciscan tertiary monk in Koper

Ključne riječi: fra Stjepan Belić, fra Gabriel Bruni, Baromićev brevijar, franjevci trećoreci glagoljaši u Kopru

Petar Runje Samostan sv. Franje Asiškoga u Krku Trg krčkih glagoljaša 2 HR-51500 Krk 


\section{FILOZOFSKI FAKULTET SVEUČILIŠTA U ZAGREBU \\ ZAVOD ZA HRVATSKU POVIJEST \\ INSTITUTE OF CROATIAN HISTORY \\ INSTITUT FÜR KROATISCHE GESCHICHTE}
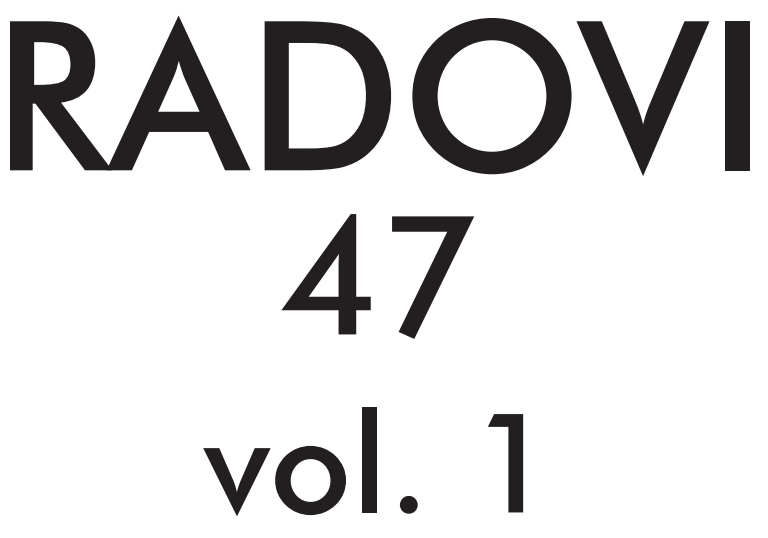

ZAVOD ZA HRVATSKU POVIJEST

FILOZOFSKOGA FAKULTETA SVEUČILIŠTA U ZAGREBU

\section{PF press \\ ZAGREB 2015.}




\title{
RADOVI ZAVODA ZA HRVATSKU POVIJEST FILOZOFSKOGA FAKULTETA SVEUČILIŠTA U ZAGREBU
}

\author{
Knjiga 47, vol. 1
}

\author{
Izdavač / Publisher \\ Zavod za hrvatsku povijest \\ Filozofskoga fakulteta Sveučilišta u Zagrebu \\ FF-press \\ Za izdavača / For Publisher \\ Vlatko Previšić \\ Glavni urednik / Editor-in-Chief \\ Hrvoje Gračanin \\ Izvršna urednica / Executive Editor \\ Inga Vilogorac Brčić \\ Uredništvo / Editorial Board
}

Bruna Kuntić-Makvić (stara povijest/ancient history), Zrinka Nikolić Jakus (srednji vijek/ medieval history), Hrvoje Petrić (rani novi vijek/early modern history), Željko Holjevac (moderna povijest/modern history), Tvrtko Jakovina (suvremena povijest/contemporary history),

Silvija Pisk (mikrohistorija i zavičajna povijest/microhistory and local history),

Zrinka Blažević (teorija i metodologija povijesti/theory and methodology of history)

Međunarodno uredničko vijeće / International Editorial Council

Denis Alimov (Sankt Peterburg), Živko Andrijašević (Nikšić), Csaba Békés (Budapest), Rajko Bratož (Ljubljana), Snježana Buzov (Columbus, Ohio), Svetlozar Eldarov (Sofija), Toni Filiposki (Skopje), Aleksandar Fotić (Beograd), Vladan Gavrilović (Novi Sad), Alojz Ivanišević (Wien),

Egidio Ivetić (Padova), Husnija Kamberović (Sarajevo), Karl Kaser (Graz),

Irina Ognyanova (Sofija), Géza Pálffy (Budapest), Ioan-Aurel Pop (Cluj),

Nade Proeva (Skopje), Alexios Savvides (Kalamata), Vlada Stanković (Beograd), Ludwig Steindorff (Kiel), Peter Štih (Ljubljana)

Izvršna urednica za tuzemnu i inozemnu razmjenu / Executive Editor for Publications Exchange Kristina Milković

Tajnik uredništva / Editorial Board Assistant

Dejan Zadro

Adresa uredništva/Editorial Board address

Zavod za hrvatsku povijest, Filozofski fakultet Zagreb, Ivana Lučića 3, HR-10 000, Zagreb

Tel. ++385 (0)1 6120 150, 6120 158, faks ++385 (0)1 6156879

Časopis izlazi jedanput godišnje / The Journal is published once a year

Časopis je u digitalnom obliku dostupan na / The Journal in digital form is accessible at Portal znanstvenih časopisa Republike Hrvatske „Hrčak“ http://hrcak.srce.hr/radovi-zhp

Financijska potpora za tisak časopisa / The Journal is published with the support by

Ministarstvo znanosti, obrazovanja i športa Republike Hrvatske

Časopis je indeksiran u sljedećim bazama / The Journal is indexed in the following databases:

Directory of Open Access Journals, EBSCO, SCOPUS, ERIH PLUS 
Naslovna stranica

Iva Mandić

Grafičko oblikovanje i računalni slog

Marko Maraković

Lektura

Samanta Paronić

Tisak

Web2tisak, Zagreb

Naklada

250 primjeraka

Časopis je u digitalnom obliku dostupan na Portalu znanstvenih časopisa Republike Hrvatske ,Hrčak“ http://hrcak.srce.hr/radovi-zhp

The Journal is accessible in digital form at the Hrcak - Portal of scientific journals of Croatia http://hrcak.srce.hr/radovi-zhp 


\section{RADOVI 47}

\section{vol. 1}

ZaVoda za hrVAtSku poviJest FILOZOFskoga fakulteta SVeuČILIŠTA u Zagrebu 


\title{
Tematski blok / Themed issue
}

\section{TREĆOREDSKA GLAGOLJAŠKA TRADICIJA U EUROPSKOM KONTEKSTU TERTIARY GLAGOLITIC TRADITION IN EUROPEAN CONTEXT}

\author{
Radovi međunarodnoga znanstvenog skupa \\ održanoga 27. i 28. IX. 2013. na Hrvatskom katoličkom sveučilištu u Zagrebu \\ u organizaciji \\ Provincije franjevaca trećoredaca glagoljaša u Zagrebu, Hrvatskoga katoličkog \\ sveučilišta u Zagrebu, Filozofskoga fakulteta Sveučilišta u Zagrebu - Odsjek za \\ povijest, Filozofskoga fakulteta Sveučilišta u Splitu - Odsjek za povijest, Instituta \\ za povijest umjetnosti u Zagrebu i Staroslavenskoga instituta u Zagrebu \\ Proceedings of the International Scientific Conference \\ held on 27th and 28th September 2013 at the Catholic University of Croatia in Zagreb \\ and organized by \\ the Province of the Glagolitic Friars of the Third Order Regular, Catholic University \\ of Croatia in Zagreb, Faculty of Humanities and Social Sciences of the University \\ of Zagreb - Department of History, Faculty of Humanities and Social Sciences of \\ the University of Split - Department of History, Institute of Art History, \\ and Old Church Slavonic Institute
}

Gosti urednici / Guest editors

\author{
Ivan BOTICA \\ Tomislav GALOVIĆ \\ Kristijan KUHAR
}

